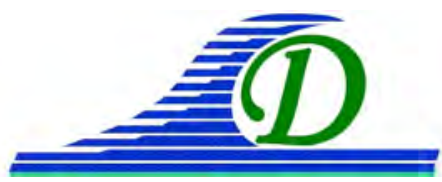
XIII ${ }^{\text {èmes }}$ Journées Nationales Génie Côtier - Génie Civil
Dunkerque, 2-4 juillet 2014

DOI:10.5150/jngcgc.2014.009 @ Editions Paralia CFL

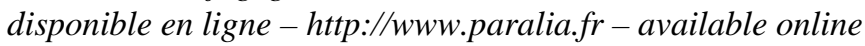

\title{
Laboratory modeling of edge wave generation over a plane beach by breaking waves
}

\author{
Alexander EZERSKY ${ }^{1}$, Nizar ABCHA ${ }^{1}$, Efim PELINOVSKY ${ }^{2}$
}

1. Université de Caen Basse Normandie, UMR 6112 CNRS, 24 rue des Tilleuls, 14000 Caen, France.

Alexander.Ezersky@unicaen.fr

2. Institute of Applied Physics, 46 Ulyanov str. 603600 Nizhny Novgorod, Russia. pelinovsky@gmail.com

\section{Communication non présentée}

\begin{abstract}
:
Results of laboratory experiments modeling an excitation of localized mode (edge waves) by breaking waves propagating towards shoreline are discussed. Investigation of edge wave excitation by breaking wave is performed in a flume where harmonic wave propagates perpendicular to plane beach and excites edge waves with half of its frequency. It is shown that the excitation of edge waves is due to parametric instability analogical to pendulum with vibrating point of suspension. The domain of instability on the plane of parameters (amplitude - frequency) of surface wave is found. It was found that for amplitude of surface wave slightly exceeding the threshold, the amplitude of edge wave grows with exponentially with time, where as for the large amplitude, the wave breaking appears and excitation of edge wave does not occur. It was shown that parametric excitation of edge wave can increase significantly (up to two times) the maximal run-up height.

Theoretical model is developed to explain suppression of instability due to turbulent viscosity. This theoretical model is based on nonlinear amplitude equation including terms responsible for parametric forcing, frequency detuning, and nonlinear detuning; linear and nonlinear edge wave damping. Dependence of coefficients on turbulent viscosity is discussed.
\end{abstract}

Keywords: Edge waves, Wave breaking, Parametric instability, Run-up, Turbulent viscosity. 
Thème 1 - Hydrodynamique côtière 
XIII ${ }^{\text {èmes }}$ Journées Nationales Génie Côtier - Génie Civil Dunkerque, 2-4 juillet 2014 
Thème 1 - Hydrodynamique côtière 
XIII ${ }^{\text {èmes }}$ Journées Nationales Génie Côtier - Génie Civil Dunkerque, 2-4 juillet 2014 
Thème 1 - Hydrodynamique côtière 
XIII ${ }^{\text {èmes }}$ Journées Nationales Génie Côtier - Génie Civil Dunkerque, 2-4 juillet 2014 
Thème 1 - Hydrodynamique côtière 
XIII ${ }^{\text {èmes }}$ Journées Nationales Génie Côtier - Génie Civil Dunkerque, 2-4 juillet 2014 
Thème 1 - Hydrodynamique côtière 